\title{
SOME OCEANOGRAPHIC FEATURES OF PELABUHANRATU BAY, WEST JAVA, INDONESIA
}

\author{
Helmy Akbar ${ }^{1,2}$, Andre Wizemann ${ }^{3}$, Ayu Ervinia ${ }^{1,4}$, Haidir llyas ${ }^{5}$, \\ Hendra Pangkey ${ }^{6}$, Kristiyanto ${ }^{7}$, Neira Purwanty Ismail ${ }^{8}$, \\ Singgih Afifa Putra ${ }^{1,9 *}$ \\ ${ }^{1}$ Department of Aquatic Resource Management, IPB University, Jawa \\ Barat, Indonesia \\ ${ }^{2}$ Department of Marine Science, Mulawarman University, Kalimantan \\ Timur, Indonesia \\ ${ }^{3}$ Department of Biochemistry and Geology, Leibniz Centre for Tropical \\ Marine Research (ZMT), Bremen, Germany \\ ${ }^{4}$ College of Environment and Ecology, Xiamen University, Xiamen, China \\ ${ }^{5}$ Department of Aquatic Resource Utilization, IPB University, Jawa Barat, \\ Indonesia \\ ${ }^{6}$ Institute of Geoscience, Christian-Albrechts-Universität zu Kiel, Kiel, \\ Germany \\ ${ }^{7}$ Faculty of Science and Technology, Syarif Hidayatullah State Islamic \\ University, Jakarta, Indonesia \\ ${ }^{8}$ Department of Marine Science and Technology, IPB University, Jawa \\ Barat, Indonesia \\ ${ }^{9}$ Department of Marine Education, Vocational Education and Training \\ Centre of Maritime and Information Technology Study (LPPPTK KPTK), \\ Ministry of Education and Culture of Indonesia, Sulawesi Selatan, \\ Indonesia \\ E-mail : singgih.afifa@kemdikbud.go.id
}

Received January 2019, Accepted April 2019

\begin{abstract}
Pelabuhanratu Bay plays a big role for the flow of nutrients from the land to the sea of Sothern-Java. This study was conducted in Pelabuhanratu Bay, Sukabumi, West Java, in March 2012. The aim of this study is to measure the oceanographic parameters (physical and chemical) of Pelabuhanratu Bay i.e. tides, waves, current, temperature, salinity, depth, density, dissolved oxygen (DO), total suspended solids (TSS), turbidity, $\mathrm{pH}$ and nutrients. The bay directly faces the Indian Ocean, during the surveyed we found mean angle of wave refraction was about $\sim 4.3^{\circ} \pm 1.5^{\circ}$, with left side wind direction. Overall the current direction has an irregular trend. The tidal cycle of the bay is diurnal, with the temperature decrease into the deep layer. Only the surface exhibits a slightly lower salinity compared to the rest of the water column. Some parameters (i.e. TSS, DO) found in high concentration but declining following the depth. Other
\end{abstract}


chemical concentrations (e.g. ortho-phosphate, silicate) also showed diminished after 10-15 depth measurement.

Keywords : Chemical, Indonesia, Pelabuhanratu Bay, Physical, Oceanography

\section{INTRODUCTION}

Oceanographic studies in Pelabuhanratu Bay have been made by several studies i.e. Wyrtki, 1961; Pariwono, 1988; Purba, 1993; Atmadipoera et al., 1994; Matsuyama et al., 1996; Sanusi, 2004; Anwar, 2008; Nugraha and Surbakti, 2009; Setiady and Sarmili, 2015. Pelabuhanratu bay is an important bay located in South oast of Java Island. Pelabuhanratu bay has an important role as one of the main fishery ports of South Java (see Sumiono, 1997; Wiyono et al. 2006; Nurani et al., 2010). As the river flows through the mainland of Java island, Pelabuhanratu Bay plays a big role for the flow of nutrients from the land to the sea (Anindita, 2002).

Routine monitoring of the oceanographic parameters is important. Historical data for an area with potential effect from anthropogenic activity surroundings will be required as a baseline study if that area get any effect in the future. Anthropogenic activity (e.g. mining activity, agriculture, deforestation, tourism) can adversely affect the surrounding waters, whether it's in the river or in the coastal waters. Evidence of bad influence from anthropogenic activity was reported by several studies (Akbar et al., 2015; Zamdial et al., 2017; Akbar et al., 2018; Putra et al., 2018).

The Pelabuhanratu Bay directly faces the Indian Ocean in the south of the island, with $20 \mathrm{~km}$ length and $18 \mathrm{~km}$ width (Matsuyama et al., 1996). That gives Pelabuhanratu Bay a unique characteristic concerning physical as well as chemical oceanographic parameters. Therefore, to study, to identify and to learn about physical and chemical oceanographic aspects of the ocean in Pelabuhanratu Bay is important for understanding coastal ecosystems. This study was conducted to measure physical and chemical oceanographic characteristics of Pelabuhanratu Bay.

The observed oceanographic parameters are interpreted as the recent environmental condition of Pelabuhanratu Bay waters and then compared to the previous reports. Changes of parameters can affect the surrounding environment in Pelabuhanratu Bay. Some of the results of this survey here will be related to the upcoming issue of ocean acidification (see Doney et al., 2009), due to the accumulation of carbon dioxide and resulting pH change (Caldeira and Wickett, 2003), which might affect the coastal ecosystem of Pelabuhanratu Bay. 


\section{MATERIALS AND METHODS}

\section{Study Location}

This study was conducted in Pelabuhanratu Bay, Sukabumi, West Java (106 $22^{\prime} 00^{\prime \prime}$ - 106 $33^{\prime} 00^{\prime \prime}$ E and 6 67'00" - $\left.7^{\circ} 07^{\prime} 00^{\prime \prime} \mathrm{S}\right)$, in March 2012. Our observation was divided into 3 locations i.e. on the beach (near marine station/ SLK IPB University), in the harbor, and in Pelabuhanratu Bay. The measurement of wave refraction angel to get an impression of sediment transport. At the harbor, we installed a measuring device to measure the tides. The measurement of oceanographic parameters (i.e. current, temperature, salinity, depth, density, dissolved oxygen, total suspended solids, turbidity, $\mathrm{pH}$ and nutrients) were done with cruise, we also take water samples for further analysis. Six stations were visited to take water samples starting from the estuary (near Cimandiri River) in direction to the open ocean (see Figure 1).

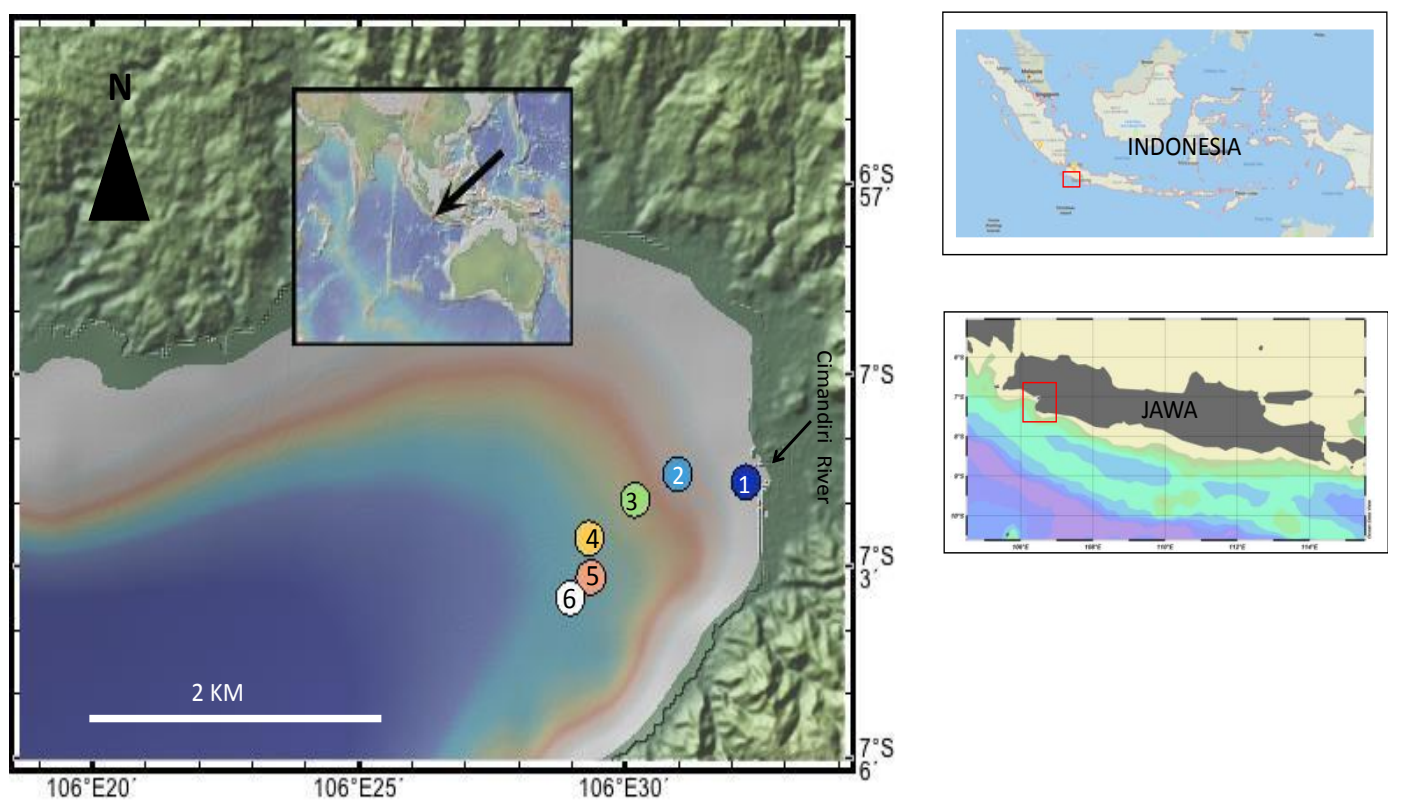

Figure 1. Map of study location in Pelabuhanratu Bay. Numbers indicate sampling sites for oceanographic parameters measurements, Station 1 (106³2'15.8" E; 701'39.8” S), Station 2 (106³0'59" E, 701'32.3” S), Station 3 (106 $30^{\prime} 11.1^{\prime \prime}$ E, $7^{\circ} 1^{\prime} 56.5^{\prime \prime}$ S), Station $4\left(106^{\circ} 29^{\prime} 19.5^{\prime \prime} \mathrm{E}\right.$, $\left.7^{\circ} 2^{\prime} 32.7^{\prime \prime} \mathrm{S}\right)$, Station $5\left(106^{\circ} 29^{\prime} 21.2^{\prime \prime} \mathrm{E}, 7^{\circ} 3^{\prime} 9.3^{\prime \prime} \mathrm{S}\right)$, Station 6 (106 $28^{\circ} 58^{\prime \prime}$ E, 703'29" S).

\section{Sampling Methods}

\section{Physical Parameters}

On the beach of the field station in Pelabuhanratu (i.e. Marine Station/ SLK IPB University), wave refraction was measured from a high 
stand position (tower) with good view over the beach and incoming waves. By the use of a tripod and a "viewing-box", the angle of refraction of the incoming waves was drawn/ noted on a transparent plastic paper. The coastline was used as a reference line to get the angle of wave refraction. The measurement was repeated 11 times to get an average angle of refraction and the direction of sediment transport.

A MOTIWALI-device (see http://mit.teknologi-kelautan.com) was placed at the harbor in Pelabuhanratu Bay to measure the tides on March $24^{\text {th }}$ to $25^{\text {th }} 2012$. Two days of measurement were necessary to get one full tide cycle. During the cruise, the conductivity, temperature, and depth profile (CTD profile) were collected on every sampling station (see Figure 1). Each profile has a depth of about $25 \mathrm{~m}$ depending on limited rope length. The parameter data was stored automatically in the CTD device. To read the data from the device the software Compact CTD was used. The data then analyzed and visualized with the software Ocean Data View / ODV (see Schlitzer, 2002).

On the stations transect, the direction and velocity of water movement in the water column was analyzed with a "current-meter". Therefore, the device was lowered to different water depths starting from 2 $\mathrm{m}$ down to $\sim 40 \mathrm{~m}$ (in steps of $10 \mathrm{~m}, 20 \mathrm{~m}$ and $30 \mathrm{~m}$ ) depending on limited rope length, current strength, and sea bottom depth of the station. The data (i.e. digitally measured by the device) was manually recorded on a data sheet. The data then visualized in a table and by using ODV.

Total Suspended Solids (TSS) and turbidity, collected using a "Nansen-bottle" water sampler $(500 \mathrm{~mL})$ from the surface layer $(1 \mathrm{~m})$ on every sampling stations of the study location. For TSS, the water is filtered on the field station in Pelabuhanratu by using filter holder and "dried filter paper". By measuring its initial weight $(A \mathrm{mg})$ and its weight afterwards (B $\mathrm{mg}$ ), the difference in weight can be calculated. The filters were analyzed in the Laboratory.

\section{Chemical Parameters}

The $\mathrm{pH}$ of seawater and dissolved oxygen (DO) profile was measured only on Station 3 in a profile of six layers in water depths of surface $(\sim 1 \mathrm{~m}), 5 \mathrm{~m}, 10 \mathrm{~m}, 15 \mathrm{~m}, 20 \mathrm{~m}$, and $25 \mathrm{~m}$. The measurement is done during the cruise by using $\mathrm{pH}$ meter. DO profile was measured with Winkler Titration method. The water was stored in $125 \mathrm{~mL}$ BOD bottles and 10 drops of $\mathrm{MnSO}_{4}$ and $\mathrm{NaOH}+\mathrm{KCl}$ were added directly. Afterwards the samples were analyzed at the field station. Therefore, 15 drops of $\mathrm{H}_{2} \mathrm{SO}_{4}$ were added to the BOD bottles and $50 \mathrm{~mL}$ were taken and filled in an Erlenmeyer-glass-bottle. Then the titration method with $\mathrm{Na}$-Thiosulfate $(0,0242 \mathrm{~N})$ was used until the color of the sample gets light yellow. Next two drops of Amylum were added until the color of the sample gets blue. The titration with $\mathrm{Na}$-Thiosulfate continues until the sample was colorless. The amount of DO was calculated by using the equation: 


$$
\mathrm{mg}_{2} / \mathrm{L}=\frac{\mathrm{ml} \mathrm{Na}-\text { Thiosulfate } \times \mathrm{N} \mathrm{Na}-\text { Thiosulfate } \times 8 \times 1000}{\text { ml sample } \times \frac{\mathrm{ml} \mathrm{BOD} \mathrm{bottle}-\text { ml reagents }}{\text { ml BOD bottle }}}
$$

For nutrient sampling, water samples were taken with a "Nansenbottle" water sampler also only on Station 3, in also six different water depths/layers. The samples were filled in $1 \mathrm{~L}$ glass bottles, sealed carefully and stored on ice. Analyzing of the samples takes place in the laboratory.

\section{Laboratory Analysis}

Gravimetric analysis was used to determine total suspended solids (TSS). Samples that have been uniformly shaken were filtered through standard glass filters that have been previously weighted and the residue left behind was dried at a temperature of $103^{\circ}-105^{\circ} \mathrm{C}$ to a fixed weight. The weight increase of the filter represents total suspended solids. The turbidity of each sample is measured with a digital turbidity-meter (NTU/ Nephelometric Turbidity Unit). Ortho-Phosphate, silicate and Nitrate were analyzed in the Laboratorium Produktivitas Lingkungan at Institut Pertanian Bogor. The water samples were filtered with a membrane filter by using a vacuum pump. After filtering of the seawater samples, proceeding with the analysis-treatment for the different nutrient analysis.

For ortho-Phosphate analysis (Ascorbic acid method; APHA 2005), $35 \mathrm{~mL}$ of the filtered seawater sample is filled in Beaker-glasses, which were pre-cleaned with $\mathrm{HCL}$ and aqua-dest. Afterwards $1 \mathrm{~mL}$ of mix reagents and $1 \mathrm{~mL}$ of ascorbic acid were added. After waiting for 5 minutes the samples was analyzed in a digital spectro-photometer at a wavelength of $880 \mathrm{~nm}$ to get the absorbance. The concentration of orthoPhosphate then calculated by using the equation:

$$
\text { Concentration }(m g / L)=\frac{a b s-0,0130}{0,6983} ; \mathrm{R}=0,9997
$$

For the Silicate analysis, $10 \mathrm{~mL}$ of filtered seawater sample is filled in a pre-cleaned plastic reaction-glass and $0.3 \mathrm{~mL}$ of $\mathrm{mix}$ reagents for seaSilicate is added. After waiting for $10-20$ minutes $0.2 \mathrm{~mL}$ of oxalic acid and $0.2 \mathrm{~mL}$ of ascorbic acid are added. Finally, after waiting again for another 30 minutes. the sample is analyzed with a digital spectro-photometer at $810 \mathrm{~nm}$ wavelength to get the absorbance. The concentration of Silicate is then calculated by using the equation:

$$
\text { Concentration }(m g / L)=\frac{a b s-0,0310}{0,3480}
$$

For the Nitrate analysis (Brucine method; APHA 1976), $5 \mathrm{~mL}$ of the filtered seawater sample was filled in a reaction-glass. $0.5 \mathrm{~mL}$ of Brucine and $5 \mathrm{~mL}$ of $\mathrm{H}_{2} \mathrm{SO}_{4}$ were added carefully in the clean-bench. The samples the heated in a water bath for half an hour. After cooling, the samples 
were analyzed with a digital spectro-photometer at a wavelength of 410 $\mathrm{nm}$ to get the rate of absorbance. The concentration of Nitrate then calculated by using the equation:

$$
\text { Concentration }(m g / L)=\frac{a b s-0,0125}{0,4340} ; \mathrm{R}=0,9998
$$

\section{RESULTS AND DISCUSSION}

\section{Physical Oceanographic Parameters}

The most significant environmental feature of the near-shore region that water depth is shallow and change rapidly. The shallow depths mean that ocean surface wave can "feel" the bottom, which causes a change in how waves move, or propagate, along the surface, and a change in the shape of the wave as the depth gets shallower (Dean and Dalrymple, 1991). A general rule of thumb is that a wave will start to be affected by water depth when the depth is less than or equal to half the wavelength. At this point, two main effect will start to occur. The first effect is that the wave will start to turn toward shore so that eventually the wave crests become parallel to the shoreline regardless of the angle at which they started in deeper water. This turning is referred to as wave refraction, and it occurs more rapidly (i.e, over shorter lengths) for regions where the depth is getting shallow faster than in regions where the depth change is gradual. Naturally, if the waves start in deep water with their crests parallel to shore, then wave refraction cannot be seen since there is no turning.

The direction of wave refraction leads to the conclusion that the sediment transport on the beach is taking place in right direction to the coastline on the observed part of the beach. Result from study, the angle of refraction with around $3^{\circ}$ to $6^{\circ}$ is relatively weak, so the erosion of the coastline is not very strong. The special form of the Pelabuhanratu Bay contributes to the formation of a jetty effect, shown here by the measurement of different wave refraction directions (left and right). This effect stands for the imbalance of sediment acression and erosion in different parts of the beach at the coastline in Pelabuhanratu Bay.

The tidal cycle in Pelabuhanratu harbor during March $24^{\text {th }}$ to $25^{\text {th }}$ 2012 is diurnal (see Figure 2). High tide is on the March $24^{\text {th }} 2012$ at $\sim 20: 40 \mathrm{~h}$; low tides are on March $24^{\text {th }} 2012$ at $\sim 15: 10 \mathrm{~h}$ and on March $25^{\text {th }}$ 12 at $\sim 2: 25$ h. Previous study (Nugraha and Surbakti, 2009) showed tidal cycle of Pelabuhanratu is dominant semidiurnal at spring tide, but at neap tide condition may be have diurnal character.

The different temperature curves for the six sampled stations were measured (see Figure 3). The temperature generally decreases into the deep layer. It is caused by the intensity of sunshine. The surface layer is the highest temperature than the others and contrary to the deep layer is the less temperature. Vertical distribution profile indicates only two layers: the thermocline layer and the depth layer. The thermocline layer is layer that extremely changes in temperature increasing the depth. Similar data with Anwar (2008), the distribution of surface temperature at 
Pelabuhanratu Bay between $27.55-27.97^{\circ} \mathrm{C}$ with a maximum depth of 18 $\mathrm{m}$. The results of Pariwono et al., (1988) got the same result at the end of east-Monsoon between September to October that is $26.0^{\circ} \mathrm{C}$ and at the beginning of west-Monsoon between November to December about 28.0 ${ }^{\circ} \mathrm{C}$.

In addition, the difference of sea surface temperature in the southern waters of Java between east-Monsoon (July-September) and west-Monsoon (December-May) also explained by Wyrtki (1961), that is $25.6{ }^{\circ} \mathrm{C}$ to $26.2{ }^{\circ} \mathrm{C}$ and $28{ }^{\circ} \mathrm{C}$. However, according to Effendie (2003) the range of temperatures, suitable for growth of phytoplankton and zooplankton as food for fish larvae.

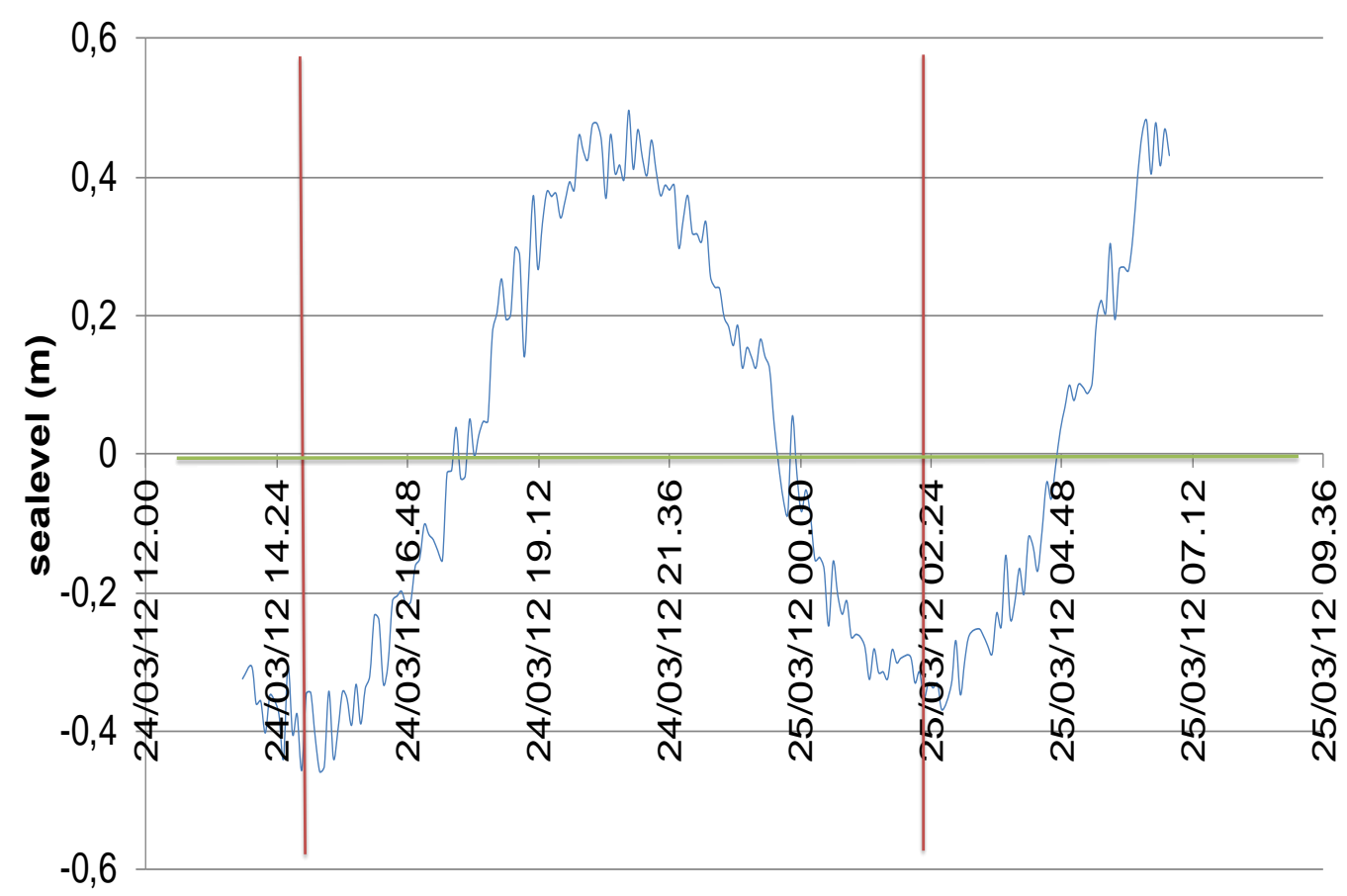

Figure 2. Tidal cycle in Pelabuhanratu Bay on $24^{\text {th }}$ to $25^{\text {th }} 2012$. The $Y$ axis shows the difference in sea-level to mean sea-level (green line). The $\mathrm{X}$-axis shows the date of the measurement. The space between the red lines mark one daily tidal cycle. One full day (red lines) shows one peak and one low tide. 


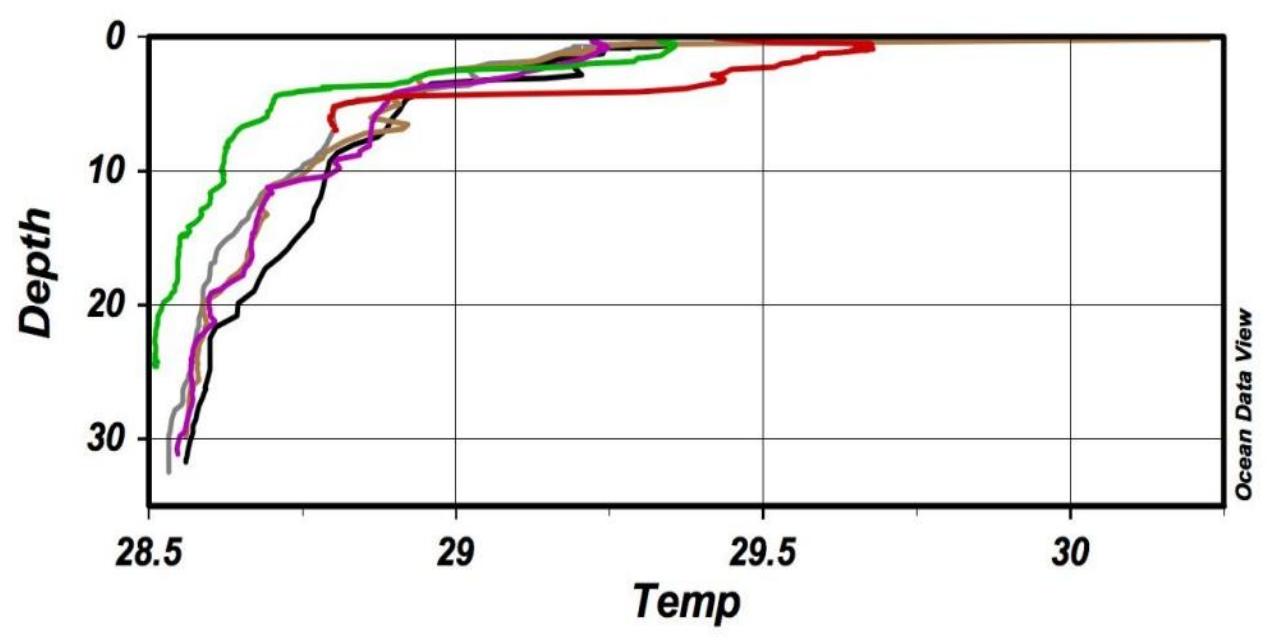

Figure 3. Vertical temperature profiles (in ${ }^{\circ} \mathrm{C}$ ) at Pelabuhanratu Bay. Station $1=$ red line; Station $2=$ green line; Station $3=$ purple line; Station $4=$ brownish line; Station $5=$ grey line; Station $6=$ black line.

Water current is one of the important physical oceanographic parameters related to the water mass transport in the ocean. Current has an important role for horizontal and vertical transport in ocean layer such as e.g. heat, suspended solid, sedimentation, run off nutrient (see Putra, 2010; Hutari et al., 2018). Ocean current in Pelabuhanratu Bay was measured in six stations starting from the closest location to the river mouth, up to the farthest sampling point from the river mouth (closer to the open ocean), current was measured at five different depth layers of each station (see Table 1).

The water current at Station 1 was only measured in 2 different depth layers caused by the sea bottom depth of less than 20 meter. At Station 1, in 2 meters of water depth, the current speed is $31.2 \mathrm{~m} / \mathrm{s}$ in direction $93.2^{\circ}$, in 10 meters of water depth the current speed is $27.5 \mathrm{~m} / \mathrm{s}$ in direction $92.1^{\circ}$. At Station 2, the current is only measured at four different depth layers caused by the sea bottom depth of less than 40 meters. At Station 2, in 2 meters of water depth, the current speed is 38.5 $\mathrm{m} / \mathrm{s}$ in direction $80.3^{\circ}$, in 10 meters the current speed is $29.8 \mathrm{~m} / \mathrm{s}$ in direction $104.4^{\circ}$, in 20 meters the current speed is $21.8 \mathrm{~m} / \mathrm{s}$ in direction $101.6^{\circ}$ and in 30 meters the current speed is $30.8 \mathrm{~m} / \mathrm{s}$ in direction $113^{\circ}$. At Station 3 the current was only measured at four different depth layers caused by the same situation as at Station 2 with less than 40 meter of water depth. At Station 4, 5 and 6, the current was measured in five different depth layers as the water depth at these Stations reached 40 meter or more.

The trend of the current data shows that the surface current exhibits a higher speed than the current in the layers below the surface. The speed of the surface current is around $19.1 \mathrm{~m} / \mathrm{s}$ up to $44.4 \mathrm{~m} / \mathrm{s}$. According to the speed of the current measured in the surface layer, Pelabuhanratu Bay has a relatively high current speed, thus the bay exhibits a strong water 
mass transport in the surface layer. In the deeper layers, the current speed is getting weaker. The current speed below the surface at 40 meter is around $10.5 \mathrm{~m} / \mathrm{s}$ up to $15 \mathrm{~m} / \mathrm{s}$.

Overall the current direction has an irregular trend. Each current speed and different depth layer have a various direction. This is caused by the inhomogeneous method of current data measurement, whereby only one point at each station is measured at a distinct water depth and the current velocity is not measured continuously throughout the whole water column. The ocean current speed also influenced by wind drift, precipitation-evaporation, and other factors (Munk, 1950; Stommel, 1957). According to Purba (2014), wind speed and wave height in Southern part of West Java ranged between $5.31-1.26 \mathrm{~m} / \mathrm{s}$ and 0.40-3.10 m, respectively.

Table 1. Water current measurement on six stations at different water depths (i.e. 2 m, 10m, 20m, 30m, 40m) in Pelabuhanratu Bay.

\begin{tabular}{|c|c|c|c|c|c|}
\hline \multirow{2}{*}{$\begin{array}{l}\text { Sampling } \\
\text { sites }\end{array}$} & \multicolumn{5}{|c|}{ Current speed (m/s) } \\
\hline & d1 (2m) & $\begin{array}{c}\mathrm{d} 2 \\
(10 \mathrm{~m})\end{array}$ & $\begin{array}{c}d 3 \\
(20 m)\end{array}$ & $\begin{array}{c}d 4 \\
(30 \mathrm{~m})\end{array}$ & $\begin{array}{c}d 5 \\
(40 \mathrm{~m})\end{array}$ \\
\hline Station 1 & 31.2 & 27.5 & - & - & - \\
\hline Station 2 & 38.5 & 29.8 & 21.8 & 30.8 & - \\
\hline Station 3 & 20.8 & 32.2 & 27.4 & 17.5 & - \\
\hline Station 4 & 44.4 & 25.2 & 18.3 & 17.3 & 12.6 \\
\hline Station 5 & 19.1 & 12.9 & 13.4 & 11.4 & 10.5 \\
\hline \multirow[t]{3}{*}{ Station 6} & 43.8 & 25.6 & 20.6 & 19.7 & 15 \\
\hline & \multicolumn{5}{|c|}{ Current direction (degrees) } \\
\hline & d1 (2m) & $\begin{array}{l}\mathrm{d} 2 \\
(10 \mathrm{~m})\end{array}$ & $\begin{array}{l}\text { d3 } \\
(20 m)\end{array}$ & $\begin{array}{l}\mathrm{d} 4 \\
(30 \mathrm{~m})\end{array}$ & $\begin{array}{l}\text { d5 } \\
(40 m)\end{array}$ \\
\hline Station 1 & 93.2 & 92.1 & - & - & - \\
\hline Station 2 & 80.3 & 104.4 & 101.6 & 113 & - \\
\hline Station 3 & 39.2 & 71 & 101.1 & 99 & - \\
\hline Station 4 & 54.2 & 82.5 & 68.6 & 70 & 65.1 \\
\hline Station 5 & 73.2 & 133.8 & 100.5 & 81.2 & 86.6 \\
\hline Station 6 & 109.4 & 117.5 & 131.1 & 110.5 & 130.4 \\
\hline
\end{tabular}

Measurement of current at Pelabuhanratu Bay in September 2004 showing maximum current $0.12 \mathrm{~m} / \mathrm{s}$ with average $0.5 \mathrm{~m} / \mathrm{s}$, with dominance direction to south, while from the simulation results (on location and the same fairy as the measurement), tidal speed can reach $0.11 \mathrm{~m} / \mathrm{s}$ and averages $0.37 \mathrm{~m} / \mathrm{s}$ with the dominant direction Head south (Nugraha, 2009). Anwar (2008) get the average monthly for current is only $6.9 \mathrm{~cm} / \mathrm{s}$ for all station at November (this month the transition from east to west monsoon) and current speed is rising again on December to March. At the time shows the same velocity of $1-1.05 \mathrm{~cm} / \mathrm{s}$, because between December and March has entered the west monsoon. In April declined again (transition season west to east) that is $9.28 \mathrm{~cm} / \mathrm{sec}$. 
Total suspended solids (TSS) are the total amount of solids suspended in the water, such as sludge, sand, and residue from dead organisms. Thereby the turbidity is formed by dissolved and suspended materials, which give the water a visible color. Horizontal distribution of TSS and turbidity from Station 1 (near Cimandiri River) until Station 6 are shown in Figure 4a-b. Station 1 exhibits the highest Turbidity of all stations (7.96 NTU). That indicates the existence of a lot of material at Station 1. The location of Station 1 is close to the mouth of Cimandiri River, which provides dissolved and particulate substance mainly released by human activities. In addition, Station 1 is in the shallow water that intensively promote friction between the water and the sediment. Therefore, the water becomes rich in particulate substances. The turbidity values strongly decrease away from the mouth of the Cimandiri River.

Given an ideal environmental condition, turbidity is influenced by TSS, as high TSS are caused the high turbidity. However, in our result there is no correlation between TSS and turbidity. A high value in TSS does not occur at Station 1, but at Station 4 (66 mg/L). Probably, there are any mismeasurements of TSS or other sources of material (e.g. particles released by the ship) on Station 4 and 5 .

TSS concentration is given in $\mathrm{mg} / \mathrm{L}$, whereas Turbidity is measured in nephelometric turbidity units (NTU's). The range of turbidity values during observation at the study site is 0.5-78 NTU (Anwar, 2008), the lowest turbidity is generally obtained in the middle of the bay and decreases the value of its NTU as the depth increases, on the contrary it increases with depth, especially three stations near the mouth of the Cimandiri River estuary. In coastal waters these turbidity particles are commonly derived from river flow (watershed), run off water, and dry deposition it on into the mouth of the Cimandiri River.

\section{Chemical Oceanographic Parameters}

No halocline shown from vertical salinity measurement, due to the limited rope length and the well-mixed water column (see Figure 4c). Only the surface exhibits a slightly lower salinity ( 31-32 psu) compared to the rest of the water column ( 33-34 psu). This is probably due to fresh water influence from the nearby river. The study by Anwar (2008) shows a relatively equal and non-fluctuating salinity between 33-35 psu. For some stations close to the mouth of the river has a fluctuating salinity between 20-31 psu and 25-29 psu.

Salinity in the waters of Pelabuhanratu Bay is influenced by the river charge. Input of water charge from river especially in the West Monsoon resulted decrease the salinity of coastal waters of Pelabuhanratu Bay. Furthermore, salinity and also temperature will be affected the density function. The surface layer is less dense than the deeper layers because salinity is less, too. This is due to freshwater influence from the mainland (e.g. river discharge) (see Matsuyama et al., 1996; Sanusi, 2004). Profile of vertical density shown at Figure 4d. 

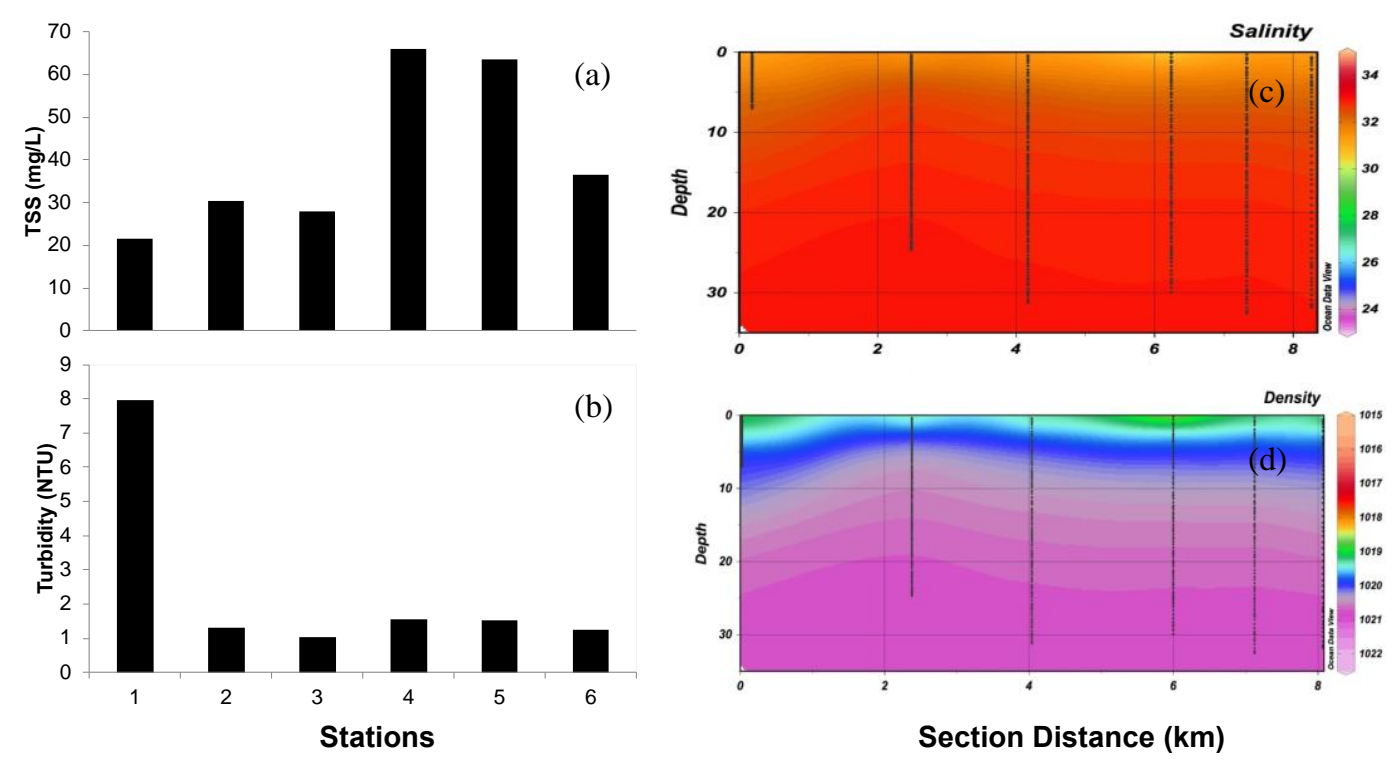

Figure 4. Horizontal Distribution of TSS (a) and Turbidity (b) in the surface layer $(\sim 1 \mathrm{~m})$ at the six stations. Vertical salinity (c) and density (d) profiles shown as gridded field (d). The black lines represent the six sampled stations from left to right. The difference in water depth (in $\mathrm{m}$ ) results from sea bottom (Station 1) and limited rope length (all other stations). Thus, the shown water depth $(\mathrm{m})$ is not representative for depth of the sea bottom. Salinity is given in parts per million (psu). For the space between stations the salinity (psu) is modeled/extrapolated from the measured values on each station. Density is given in $\mathrm{kg} / \mathrm{m}^{3}$.

\section{Correlation of $\mathrm{pH}$ and Dissolved Oxygen (DO)}

Vertically fluctuation of $\mathrm{pH}$ and $\mathrm{DO}$ were measured only on station 3 to obtain a vertical distribution in six layers of water depth of $0 \mathrm{~m}, 5 \mathrm{~m}, 10$ $\mathrm{m}, 15 \mathrm{~m}, 20 \mathrm{~m}$, and $25 \mathrm{~m}$ (see Figure $5 \mathrm{a}-\mathrm{b}$ ). The $\mathrm{pH}$ on surface layer is higher than the $\mathrm{pH}$ of the deeper layers $(7,94-8,08)$. The $\mathrm{pH}$ is influenced by the amount of $\mathrm{CO}_{2}$ (a lot of $\mathrm{CO}_{2} \rightarrow$ low $\mathrm{pH}$; little $\mathrm{CO}_{2} \rightarrow$ high $\mathrm{pH}$ ) in the water column. A decrease of $\mathrm{CO}_{2}$ in the water can occur, when it gets absorbed by phytoplankton for photosynthesis. Photosynthesis only occurs in the surface layer, due to the process is depending on sufficient light. Therefore, it causes $\mathrm{pH}$ in surface layer to become higher. In contrast, an increase in $\mathrm{CO}_{2}$ is caused by the respiration of marine organisms (e.g. zooplankton) and the decomposition of organic matter, which both usually occur in deeper water layers.

Similar with Anwar (2008), the level of acidity obtained during observations in the Pelabuhanratu Bay shows almost the same value in the whole station that is about 7.6-8.2. The $\mathrm{pH}$ distribution of stations 2 - 9 is relatively constant, according to Romimohtarto and Juwana (2001) this is related to the ability of the bay to stabilize $\mathrm{pH}$ change.

Figure $5 b$ shows a declining dissolved oxygen concentration (4,71$7,46 \mathrm{mg} / \mathrm{L})$ in dependence to an increase in depth. The decrease of DO with depth is the result of a decrease in photosynthesis, as 
photosynthesizing organisms only occur in the photic zone that provides sufficient light. Therefore, oxygen production and also the diffusion from air to the atmosphere is intensive in the surface layer. In contrast, respiration which consumes oxygen dominates in the deeper layers. Therefore, the surface layer is richer in oxygen than the deeper layers. Additionally, in the deep and bottom layer oxygen is also required for decomposition and remineralization of organic matter by bacteria and detritivores.

Anwar (2008) found the dissolved oxygen data obtained when the observations at the surface layer at were $2.03-8.9 \mathrm{mg} / \mathrm{L}$. Possibility, condition low of DO values obtained due to sampling are done at night and oceanographic conditions relatively quiet. so that the diffusion with very little atmosphere and photosynthetic activity from phytoplankton doesn't giving oxygen input. Also, respiratory activity of aquatic organisms which tend only utilize oxygen at night.

\section{Correlation of Nitrate, Phosphate and Silica with Depth}

In Figure $5 \mathrm{c}$ Nitrate concentration is about $\sim 0.377 \mathrm{mg} / \mathrm{L}$ on the surface down to $5 \mathrm{~m}$ water depths. In $10 \mathrm{~m}$ of water depths it gets diminished to $0.36 \mathrm{mg} / \mathrm{L}$ and rises over $0.37 \mathrm{mg} / \mathrm{L}$ in $15 \mathrm{~m}$ water depth up to $0.42 \mathrm{mg} / \mathrm{L}$ in $20 \mathrm{~m}$ water depth. Again, Nitrate gets diminished to $\sim 0.36$ $\mathrm{mg} / \mathrm{L}$ in $25 \mathrm{~m}$ water depths. In the surface layers, $0 \mathrm{~m}$ to $10 \mathrm{~m}$, nitrate is consumed by phytoplankton.

Where light is insufficient for photosynthesis and therefor no phytoplankton growth occurs, the concentration of Nitrate rises again. In water depth of about $20 \mathrm{~m}$ to $25 \mathrm{~m}$ Nitrate gets consumed again, but this time its degraded by bacterial processes over Nitrite to Ammonium. Result of the study both within the period of northwest monsoon (December 1993) and east monsoon (July 1994) (in Sanusi, 2004) showed that nutrient element concentrations (i.e. NO3-N, NH4-N, PO4-P) were relatively low for the optimum requirement of photosynthetic process of the phytoplankton.

The results shown in Figure $5 \mathrm{~d}$, lead to the conclusion that the concentration of ortho-Phosphate $(0.005 \mathrm{mg} / \mathrm{L})$ is below the limit of detection for the method used in our laboratory, which is $<0.05 \mathrm{mg} / \mathrm{L}$. In Figure $5 \mathrm{e}$, Silicate concentration is above $0.1 \mathrm{mg} / \mathrm{L}$ at the surface and up to $0.12 \mathrm{mg} / \mathrm{L}$. Then the concentration rapidly gets diminished over 0.06 $\mathrm{mg} / \mathrm{L}$ at $10 \mathrm{~m}$ to almost zero $\mathrm{mg} / \mathrm{L}$ in $15 \mathrm{~m}$ of water depth and beyond. In the surface layers of $0 \mathrm{~m}$ to $5 \mathrm{~m}$ the silicate phytoplankton consumes most of the silicate in the water column for building their test and shells, leading to silica depletion in the deeper layers. 

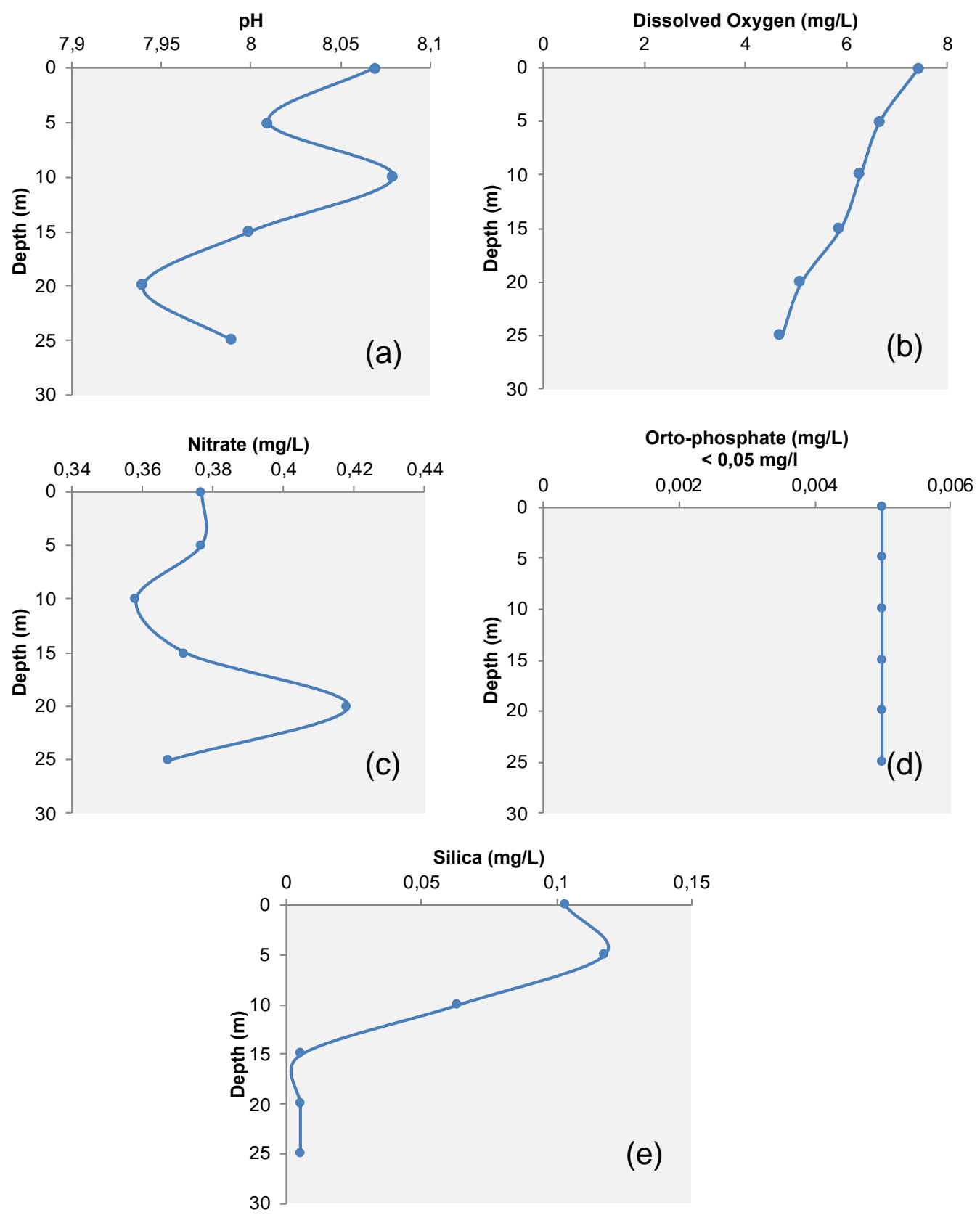

Figure 5. Depth profile of $\mathrm{pH}(\mathrm{a})$, dissolved oxygen (b), nitrite (c), orthophosphate (d), Silica (e). Six water layers are sampled starting from surface down to $25 \mathrm{~m}$ of water depth.

This result is lower than study from Sanusi (2004), cause during northwest monsoon, the nutrient concentrations of dissolved $\mathrm{SiO} 2$ both at the surface waters $(37.56-151.68 \mathrm{mg} \mathrm{SiO} / \mathrm{l})$ and at $25 \mathrm{~m}$ depth $(3.97-$ $39.19 \mathrm{mg} \mathrm{SiO} / \mathrm{l}$ ) are known higher than $2.0 \mathrm{mgSiO} / / \mathrm{l}$ as normal average concentration. In contrast, during east monsoon $\mathrm{SiO} 2$ concentration were lower at the range of $0.135-0.995 \mathrm{mg} \mathrm{SiO} 2 /$ land $0.132-0.218 \mathrm{mg} \mathrm{SiO} 2 / \mathrm{l}$ for surface and $25 \mathrm{~m}$ depth. 
The availability of nutrient elements in the Pelabuhanratu Bay influenced beside are affected by photosynthetic activity, river discharge (as allogenic elements) and high suspended solids (79-660 mg/l) carried by the river, especially at northwest monsoon. Vertical distribution (up to $25 \mathrm{~m}$ depth) of the nutrient elements for the two seasons tend to deplete especially for silicate, phosphate and nitrate at northwest monsoon. Relatively low concentration of nutrient elements at $25 \mathrm{~m}$ depth were followed by low abundance of plankton population compared to that recorded at the surface water (Sanusi, 2004).

In term of abundance of plankton and benthic organisms during northwest monsoon the productivity waters were considered low up to medium. On the contrary the productivity of the waters was relatively high indicated by high abundance of plankton population during east monsoon. As with other nutrient groups, silica also shows an increase in stations close to the bottom or lower depths. High concentrations in the waters of Pelabuhanratu Bay are linked to land inputs, especially at estuary stations due to the mega-project activity of the Cimandiri Electric Steam Power Plant (Sanusi, 2004).

\section{CONCLUSIONS}

The results of observations made in the study of physics and chemistry oceanography this time showed results that do not vary much with the results of previous research. Differences in the results of the analysis can occur because the time of the survey, whether in the west season, east seasons or transitional seasons and whether or not the phenomenon of natural upwelling. As a note, routine monitoring of the physical and chemical parameters of the Pelabuhanratu Bay is required. Anthropogenic activity such as the construction of Cimandiri Steam Power Plant, waste disposal around the bay, river basin damaged by physical development activities may alter existing oceanographic conditions at the Pelabuhanratu Bay.

\section{ACKNOWLEDGEMENT}

Thanks to Marine Science and Technology (MST) Training 2012 Committee for provide the fieldtrip in the Pelabuhanratu Bay. Several MST Training assistants help with accommodations and logistics during the fieldtrip. 


\section{REFERENCES}

Akbar, H., A. Damar, M.M. Kamal, K. Soewardi, \& S.A. Putra. 2015. Distribusi logam berat pada air dan sedimen laut di wilayah pesisir Kabupaten Sumbawa Barat. OmniAkuatika 11(2): 61-65.

Akbar, H., I. Suyatna, Jailani, S.A. Putra, \& F. Azmi. 2018. Effects of anthropogenic activity on stream water quality in Langsa, Aceh. Jurnal Biologi Tropis 18(2): 200-207.

Anindita, A.D. 2002. Kandungan logam berat $\mathrm{Cd}, \mathrm{Cu}, \mathrm{Ni}, \mathrm{Pb}$ dan $\mathrm{Zn}$ terlarut dalam badan air dan sedimen pada perairan sekitar pelabuhan perikanan Pelabuhan Ratu, Sukabumi. Thesis. Institut Pertanian Bogor, Jawa Barat.

Anwar, N. 2008. Karakteristik Fisika Kimia Perairan dan Kaitannya dengan Distribusi serta Kelimpahan Larva Ikan di Teluk Palabuhan Ratu. Thesis. Institut Pertanian Bogor, Jawa Barat.

Atmadipoera, A.S., N.M.N. Natih, \& Zairion. 1994. Studi Sifat Fisik dan Kimia Oseanografi di Perairan Teluk Palabuhan Ratu. LPPM, Institut Pertanian Bogor, Jawa Barat.

Effendie, H. 2003. Telaah Kualitas Air bagi Pengelolaan Sumberdaya dan Lingkungan Perairan. Penerbit Kanisius, Yogyakarta. 256 pp.

Caldeira, K., \& M.E. Wickett. 2003. Oceanography: anthropogenic carbon and ocean pH. Nature, 425(6956): 365.

Dean, R.G., \& R.A. Dalrymple. 1991. Water Wave Mechanics for Engineers and Scientists. World Scientific, Science. 353 pp.

Doney, S.C., V.J. Fabry, R.A. Feely, \& J.A. Kleypas. 2009. Ocean Acidification: The Other CO2 Problem. Annual Reviews of Marine Science 1: 169-192. doi: 10.1146/annurev.marine.010908.163834.

Hutari, P.Z., Y. Johan, B.F.S.P. Negara. 2018. Analisis sedimentasi di Pelabuhan Pulau Baai, Kota Bengkulu. Jurnal Enggano 3(1): 129143.

Matsuyama, M., T. Senjyu, \& N.M.N. Natih. 1996. Oceanographic condition in Palabuhan Ratu Bay, West Java. La mer 34: 283-291

Munk, W.H. 1950. On the wind-driven ocean circulation. Journal of Meteorology 7(2): 79-93. 
Nugraha, R.B.A., \& H. Surbakti. 2009. The Simulation of Two Dimensional Current in Pelabuhan Ratu Bay in September 2004. Jurnal Kelautan Nasional 4(1): 48-55.

Nurani, T.W., E. Lubis, J. Haluan, \& S. Saad. 2010. Analysis of fishing ports to support the development of tuna fisheries in the south coast of Java. Ind. Fish Res. J. 16(2): 69-78.

Pariwono, J.I., M. Eidman, S. Rahardjo, M. Purba, T. Prartono, R. Widodo, U. Djuariah, \& J.H. Hutapea. 1988. Studi Up-welling di Perairan Selatan Jawa. LPPM, Institut Pertanian Bogor, Jawa Barat.

Purba, M. 1993. Evolusi (Perkembangan) Proses Upwelling dan Sifat Sifat Oseanografi yang diakibatkannya, di perairan Selatan Jawa Barat. LPPM, Institut Pertanian Bogor.

Purba, N.P. 2014. Variabilitas angina dan gelombang laut sebagai energi terbarukan di Pantai Selatan Jawa Barat. Jurnal Akuatika 5(1): 815.

Putra, S.A. 2010. Proses Sedimentasi di Muara Sungai Batang Arau, Kota Padang. Jurusan IImu Kelautan. Thesis. Universitas Riau, Pekanbaru.

Putra, S.A., I.A. Syari, H. Akbar, I. Suyatna, \& D.H.E. Setiamarga. 2018. Human activities and persistent coral reef degradation in Gaspar Strait, Bangka Belitung Islands, Indonesia [version 1; referees: awaiting peer review]. F1000Research 7:1962. doi: 10.12688/f1000research.16519.1

Romimohtarto, K., \& S. Juwana. 2001. Biologi Laut Ilmu Pengetahuan Tentang Biota Laut. Djambatan, Jakarta. 540 pp.

Sanusi, H. 2004. Chemical Characteristic and Fertility of Pelabuhan Ratu Bay Waters at East and West Monsoon. Jurnal IImu-ilmu Perairan dan Perikanan Indonesia. 11(2): 93-100.

Schlitzer, R. 2002. Interactive analysis and visualization of geoscience data with Ocean Data View. Computers \& Geosciences 28(10): 1211-1218.

Setiady, D., \& L. Sarmili. 2015. Proses akrasi dan abrasi berdasarkan pemetaan karakteristik pantai dan data gelombang di teluk Pelabuhanratu dan Ciletuh, Kabupaten Sukabumi, Jawa Barat. Jurnal Geologi Kelautan. 13(1): 37-47.

Stommel, H. 1957. A survey of ocean current theory. Deep-Sea Res. 4(3): 149-184. 
Sumiono, B. 1997. Fishing activities in relation to commercial and smallscale fisheries in Indonesia. In Proceedings of the Regional Workshop on Responsible Fishing, Bangkok, Thailand, 24-27 June 1997. Training Department, Southeast Asian Fisheries Development Center. p: 41-70.

Wiyono, E.S., S. Yamada, E. Tanaka, T. Arimoto, \& T. Kitakado. 2006. Fishing strategy for target species of small-scale fisheries in Pelabuhanratu Bay, Indonesia. La mer 44: 85-93.

Wyrtki, K. 1961, Physical Oceanography of the South East Asian Waters, Naga Report Vol. 2. Scripps Institute of Oceanography, California.

Zamdial, D. Hartono, D. Bakhtiar, E. Nofridiansyah. 2017. Studi identifikasi kerusakan wilayah pesisir di Kabupaten Mukomuko, Provinsi Bengkulu. Jurnal Enggano 2(2): 196-207. 